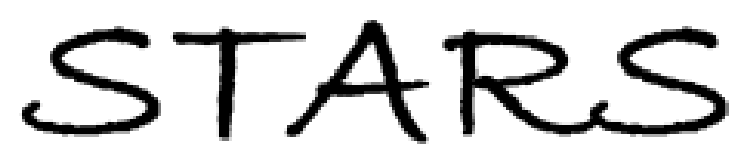

University of Central Florida

STARS

Faculty Scholarship and Creative Works

2013

\title{
Hospitality Management: A Guide to Key Reference Works
}

Tim Bottorff

University of Central Florida, timothy.bottorff@ucf.edu

Part of the Collection Development and Management Commons

Find similar works at: https://stars.library.ucf.edu/ucfscholar

University of Central Florida Libraries http://library.ucf.edu

This Paper is brought to you for free and open access by STARS. It has been accepted for inclusion in Faculty Scholarship and Creative Works by an authorized administrator of STARS. For more information, please contact STARS@ucf.edu.

Original Citation

Bottorff, T. (2013). Hospitality management: A guide to key reference works. Reference Services Review, $41(4), 605-622$.

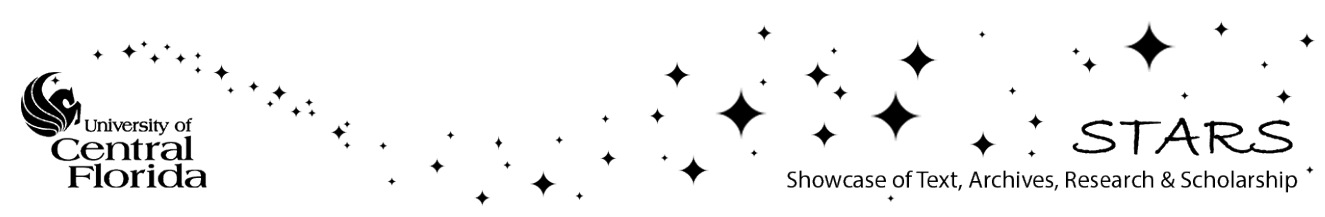




\title{
Hospitality Management: A Guide to Key Reference Works
}

\author{
By Tim Bottorff
}

\section{Introduction}

Libraries supporting undergraduate and/or graduate level hospitality management courses need to collect materials related to many diverse industries, including food and beverage, lodging, meetings and special events, travel and tourism, and theme parks and attractions. This article provides the first comprehensive review of the major books, databases, websites, and other resources that comprise a quality hospitality management reference collection.

The term hospitality generally refers to the set of businesses and organizations that provide services to travelers: food, lodging, and travel. An ancient profession, the provision of hospitality has only recently been recognized for the multi-billion dollar industry that it truly is — and, in today's sluggish economy, for its impact on the job market.

In fact, the U.S. hospitality industry is one of the nation's largest employers, supporting more than 7.5 million jobs annually (USTA, Economic Review, 2011-12). The travel industry alone ranks fifth in terms of private industry employment and payroll in the United States, after only health care, retail, manufacturing, and administrative jobs (USTA, Travel and Tourism, 201011). Globally, the United Nations World Tourism Organization reports, the hospitality industry employs one in eleven people and accounts for approximately $9 \%$ of the world's GDP (UNWTO, 2013).

Responding to these employment opportunities, colleges and universities around the nation are increasingly offering courses or entire degrees in fields such as tourism studies, hotel and restaurant management, and travel administration, or even in niche areas such as event management or timeshare management. Collectively, these areas of study may be placed under the rubric of hospitality management.

Hospitality management is a relatively new academic field. Until the early twentieth century, education in the various facets of hospitality came primarily through apprenticeships and on-thejob training. Hospitality entered the academy more formally starting with the establishment of the School of Hotel Administration at Cornell University in 1922 (Edmundson, 1996). By 1946, enough educators and industry executives were interested in the condition of hospitality education to form the Council on Hotel and Restaurant Education, now called the Council on Hotel, Restaurant, and Institutional Education (CHRIE) (Ryan, 1996). Nonetheless, the first scholarly journal in the field, the Cornell Hotel and Restaurant Administration Quarterly, did not appear until 1960 (Livingston, 1985), and by the early 1970s there were still only about 40 fouryear college-level programs in the United States (CHRIE, 2006).

Despite its modest beginnings, hospitality management education has grown tremendously in recent years. According to CHRIE, there are now approximately 170 accredited programs 
granting bachelor's degrees, over 45 granting graduate degrees, and more than 800 programs granting associate degrees or certificates (CHRIE, 2006).

The number and type of subjects studied in hospitality management programs varies widely. Some programs focus on just one or two aspects of the field, such as hotel and restaurant management. Others offer a broad array of courses or concentrations in areas as diverse as foodservice, lodging, meetings and conventions, travel and tourism, and theme parks and attractions. Many established programs even offer a full slate of hospitality-themed courses in subjects such as accounting, geography, human resources, law, marketing, and technology. Similarly, some programs take a more vocational, hands-on approach, in which the goal is to prepare students for entry- and mid-level hospitality positions, while others take a more management-based approach, in which the goal is to groom future industry leaders and executives.

Given the proliferation of hospitality programs in colleges and universities, many academic libraries around the nation have been working to increase their hospitality holdings and services. In fact, there are now at least four academic libraries in the United States that specialize almost entirely in hospitality management resources:

- Alice Statler Library at the City College of San Francisco http://www.ccsf.edu/NEW/en/library/about-library/library-locations/statler.html (accessed 15 July 2013)

- Massad Family Library Research Center and Hospitality Industry Archives at the University of Houston http://www.hrm.uh.edu/RESOURCES/LibraryandArchives/Massad-Family-Library-/ (accessed 15 July 2013)

- Nestlé Library at Cornell University http://www.hotelschool.cornell.edu/research/library (accessed 15 July 2013)

- Universal Orlando Foundation Library at the University of Central Florida http://library.ucf.edu/rosen (accessed 15 July 2013)

Each of these libraries offers the usual array of resources for interested researchers, such as access to the online catalog, research guides, and links to useful websites. Several other academic libraries have significant hospitality management collections, including those at Florida International University, Michigan State University, New York University, Northwestern University, Oklahoma State University, Penn State University, Purdue University, University of California Berkeley, University of Hawaii, and the University of Nevada Las Vegas.

Nonetheless, beyond the materials that may be freely accessed at the above libraries, there are very few resources for librarians seeking to improve their hospitality holdings. Articles on travel and tourism websites have either focused on sites of interest to the general public, have neglected most key print and subscription materials, or have failed to examine more specialized areas of the field (Krupar \& Auer, 2005; Zabel, 2003). The Reference \& User Services Association’s 
annual review of "Outstanding Business Reference Sources” occasionally includes a small number of hospitality titles, and monographs such as the recent ALA Guide to Economics \& Business Reference mention a few titles (Outstanding Business Reference, 2011; ALA, 2011). However, no systematic review of key reference resources in hospitality management has been undertaken.

The following guide attempts to fill that gap and will be most useful to libraries that support twoyear, four-year, or graduate level programs in hospitality management. Business librarians and general reference librarians will also discover much useful information here, as questions dealing with aspects of the hospitality and tourism field are becoming more commonplace at the general reference desk.

\section{Annotated Bibliography of Key Works}

The following selections focus on core reference works and electronic resources that are specific to hospitality management. In reality, the diverse areas of study that encompass hospitality management are very interdisciplinary in nature. Consequently, librarians wishing to successfully serve hospitality management students should also have access to at least core collections of materials in areas such as anthropology, business, geography, government, law, technology, and general reference.

\section{General Hospitality Management Resources}

For the librarian, a useful way to conceptualize the diverse parts of the sprawling field of hospitality management is to separate it into different "industries," such as the food and beverage industry, the lodging industry, the meetings and events industry, the theme park industry, and the travel and tourism industry. Each of these major areas will be treated in-depth below. In reality, of course, these different sectors overlap a great deal. The following important sources attempt to cover all or several parts of the entire field.

Brotherton, B. and Wood, R.C. (2008), SAGE Handbook of Hospitality Management, Sage, Los Angeles, CA.

As with the SAGE Handbook of Tourism Studies (see the Tourism section above), this useful work provides excellent introductory, medium-length chapters written by experts in the field. This work takes a broad view of hospitality management as a whole, covering key themes (structure, gender, education, etc.), key management functional areas (operations, financial management, marketing, human resources, etc.), and specialized sectors (lodging, meetings, food $\&$ beverage, etc.). This is a must-have work for any hospitality reference section.

Medlik, S. (2003), Dictionary of Travel, Tourism, \& Hospitality, Butterworth-Heinemann, Boston, MA. 
A good basic dictionary covering the full scope of the hospitality and tourism industries. It also includes appendices with listings of organizations, biographical entries, abbreviations, and more.

Pizam, A. (2010), International Encyclopedia of Hospitality Management, Elsevier/Butterworth-Heinemann, Boston, MA.

The first edition of this work (2005) provided the first comprehensive one-volume hospitality encyclopedia in more than a decade. This second, updated edition (2010) is a key work that should be a part of any hospitality reference section. The short to mediumlength articles are signed by experts in the field and usually include several references for further reading.

Plunkett Research (2012), Plunkett's Airline, Hotel, \& Travel Industry Almanac, Plunkett, Houston, TX.

The Plunkett's almanacs all follow a similar outline, with major content including a useful narrative section on key trends, a chapter with handy industry statistics, and a large section with company profiles (which includes some private companies on which information can be difficult to find in other sources). Another useful title for hospitality reference is Plunkett's Food Industry Almanac (2012).

World Chamber of Commerce Directory (2012), World Chamber of Commerce Directory, Loveland, CO.

This source, updated annually for more than 50 years, provides a comprehensive directory to chambers of commerce, state boards of tourism, convention and visitors bureaus, economic development councils, foreign chambers of commerce, and many other such organizations.

\section{Food \& Beverage Resources}

The U.S. food and beverage industry employs more than 13 million workers in over 980,000 locations and generates over $\$ 660$ billion in total sales each year. In fact, the restaurant industry is one of the nation's largest private employers, and career prospects in restaurants will likely remain good for the foreseeable future (NRA, 2013).

For the purposes of this review, the food and beverage industry encompasses areas such as restaurants (including quick service, casual service, fine dining, etc.), bars, cafes, catering operations, coffee shops, and food service at hotels, on airplanes, at private clubs, and at special events. Some hospitality management programs focus more on the culinary aspects of food, while others place more emphasis on the management of food and beverage operations; obviously, the library's collection must reflect this distinction. In either case, reference works on the foodservice industry are numerous and varied, so libraries wishing to cover this area well must invest considerable time and resources in the collection. 
Alcohol, Beer, and Wine:

Brostrom, G. and Brostrom, J. (2009), Business of Wine: An Encyclopedia, Greenwood Press, Westport, CN.

This handy one-volume work is unique in its focus on the business side of wine, including companies, economics, industry segments, legal issues, personalities, and more.

Appendices include international wine data, conversions, and a brief bibliography.

Domine, A. (2008), Ultimate Guide to Spirits \& Cocktails, Ullmann, Konigswinter, Germany.

Although this source is at times informal and relaxed, no other source covers spirits and cocktails as well or as comprehensively as this hefty volume. The table of contents and index allow readers to dip into it efficiently, and high-quality photographs and illustrations accompany the text throughout.

Edwards, G. and Edwards, S. (2007), Dictionary of Drink: A Guide to Every Type of Beverage, Stroud, Sutton. UK.

While the focus of this dictionary is on types of beverages (both alcoholic and nonalcoholic), also included are entries on other aspects of the beverage business, including brands, personalities, terminology, wineries, and much more.

Johnson, H. and Robinson, J. (2007), World Atlas of Wine, Mitchell Beazley, London, UK. Edited by two of the top names in modern oenology, this lavishly illustrated and wellresearched work is a key reference to the various wine growing regions of the world.

Oliver, G. (2012), Oxford Companion to Beer, Oxford University Press, New York, NY. A quality reference on the art, history, and science of beer, with entries on breweries, chemistry, companies, cultures, ingredients, personalities, styles, and much more. Also included are appendices on beer organizations, festivals, websites, magazines, newspapers, and museums.

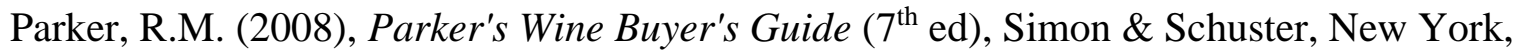
NY.

Now in its $7^{\text {th }}$ edition, this is a classic reference on wine vintages, prices, and ratings, from one of the world's foremost experts in wine.

Robinson, J. (2006), Oxford Companion to Wine, Oxford University Press, New York, NY. Like most Oxford Companion books, this work provides a solid single-volume reference to its title subject. Included are entries on wine growing regions, ingredients, personalities, specialized vocabulary, and much more, as well as lots of helpful illustrations and maps.

Robinson, J., Harding, J., and Vouillamoz, J. (2012). Wine Grapes: A Complete Guide to 1,368 Vine Varieties, Including Their Origins and Flavours, Ecco/HarperCollins, New York, NY.

This massive new tome is the most thorough and authoritative work on wine grapes to date - covering more than 1,300 different grape varieties - and it is a must-have for any serious 
wine reference collection. Also useful, especially for undergraduates, is Oz Clarke's Grapes \& Wines: A Comprehensive Guide to Varieties and Flavours, (Sterling Epicure, 2010), previous editions of which were titled Oz Clarke's Grapes \& Wines (2007) or Encyclopedia of Grapes (2001).

Food Dictionaries and Encyclopedias:

Arndt, A. (2006), Culinary Biographies, YES Press, Houston, TX.

This unique and highly recommended work fills an important niche, and its full subtitle explains its scope: A Dictionary of the World's Great Historic Chefs, Cookbook Authors and Collectors, Farmers, Gourmets, Home Economists, Nutritionists, Restaurateurs, Philosophers, Physicians, Scientists, Writers, and Others Who Influenced the Way We Eat Today. It is actually more of biographical encyclopedia than a dictionary, as most entries are two to four pages in length.

Ayto, John (2012), Diner's Dictionary: Word Origins of Food \& Drink, Oxford University Press, United Kingdom.

Of the many general food and beverage dictionaries on the market, this updated edition from John Ayto is one of the more scholarly and in-depth. Also useful are general works such as Food Lover's Companion (Barron's, 2007), International Dictionary of Gastronomy (Hippocrene Books, 2003), and Webster's New World Dictionary of Culinary Arts (Prentice Hall, 2001). Some libraries may also require more specialized works such as Dictionary of Food Science and Technology (Blackwell, 2009) and Pocket Dictionary of Food Safety (CRC Press, 2011).

Katz, S.H. (2003), Encyclopedia of Food and Culture, Scribner, New York, NY. This three-volume set remains one of the best for delving into the cultural, historical, and sociological aspects of food. Other useful works in this area include the Cambridge World History of Food (Cambridge Univ Press, 2000) and the Oxford Companion to Food (Oxford Univ Press, 2006).

Myhrvold, N. (2011), Modernist Cuisine: The Art and Science of Cooking, Cooking Lab, Bellevue, WA.

This groundbreaking set focuses on modernist "science-inspired techniques" of cooking. The six volumes (and more than 2400 pages) cover history and fundamentals, techniques and equipment, animals and plants, ingredients and preparations, plated-dish recipes, and a kitchen manual. This is an essential purchase for libraries serving culinary or restaurant management programs, but it may be too specialized (and pricy) for some more general hospitality collections.

Pilcher, J.M. (2012), Oxford Handbook of Food History, Oxford Univ Press, New York, NY.

This major new scholarly work would be an excellent addition to food reference collections, especially those serving upper-level undergraduates, graduates, and researchers. The material is organized into major chapters ("Anthropology of Food," 
"Culture of Food," "Medieval Spice Trade," and so on) that are authored by accomplished historians. Extensive notes and bibliographies also accompany the chapters.

Robuchon, J. (2009), Larousse Gastronomique: The World's Greatest Culinary Encyclopedia, Clarkson Potter/Publishers, New York, NY.

The latest in the great line of Larousse culinary encyclopedias, this work still retains its focus on French cuisine, but it has been updated for modern times and is more balanced in coverage than some of the older, classic editions. It remains a must-have for food reference collections. Hands-on culinary collections should also have the four-volume Larousse Gastronomique Recipe Collection (Clarkson Potter, 2004).

Smith, A.F. (2012), Fast Food and Junk Food: An Encyclopedia of What We Love to Eat, Greenwood, Santa Barbara, CA.

This is one of the more recent works in a long line of highly specific food encyclopedias that have been published within the last decade. Most libraries supporting food and beverage research will need this work, as well as all or several of the following selfexplanatory titles: Cultural Encyclopedia of Vegetarianism (Greenwood, 2010), Encyclopedia of Herbs (Timber Press, 2009), Encyclopedia of Jewish Food (Wiley, 2010), Encyclopedia of Kitchen History (Fitzroy Dearborn, 2004), Encyclopedia of Pasta (University of California Press, 2009), New Whole Foods Encyclopedia: A Comprehensive Resource for Healthy Eating (Penguin Books, 2010), and They Eat That?: A Cultural Encyclopedia of Weird and Exotic Food from Around the World (ABC-Clio, 2012).

Smith, A.F. (2013). Oxford Encyclopedia of Food and Drink in America, Oxford University Press, New York, NY.

Andrew F. Smith is a prolific author and editor of works on culinary history and culture, and the updated second edition of this three-volume work is essential for all food reference collections. It contains almost twice as many entries as the first edition, and the coverage includes chronological surveys, products, ethnic and cultural groups, personalities, political and social food movements, and much more.

Turner, C.L. and Randovski, J.A. (2011), Encyclopedia of Food Science Research, Nova Science Publishers, Hauppauge, NY.

The highly scientific and technical nature of this three-volume set makes it unnecessary or marginal for most general hospitality collections, but it would be indispensable to libraries serving programs with food science students and researchers. Topics include bioactive peptides, organic vegetables, food waste management, functional components of food, chemical analysis, and much more. Each of the 52 chapters includes thorough treatment of its subject and an extensive list of references.

Foodservice Industry Statistics and Trends:

Chain Store Guides (2011), Directory of Chain Restaurant Operators, Chain Store Guides, Tampa, FL.

Although most of the data in individual listings (sales, number of employees, locations, etc.) can be located online or in company databases, this directory's geographical 
breakdowns and extensive indexes (by type of foodservice, menu type, franchisee, and more) are still useful for food researchers. The publisher also produces a Directory of Food Service Distributors.

New Strategist Publications (2011), Who's Buying at Restaurants and Carry-Outs, New Strategist, Ithaca, NY.

The Bureau of Labor's Consumer Expenditure Survey (CES) is the primary source of data for this publication, but the presentation and ease of use make this a useful addition to food reference collections. It is chock-full of charts and statistics on spending at restaurants by age, income, household type, race, geography, education, and other factors. A related and similarly useful title is Who's Buying Alcoholic and Nonalcoholic Beverages (New Strategist, 2011).

Grey House Publishing (2013), Food and Beverage Market Place, Grey House, Amenia, NY.

This massive three-volume source is still the most comprehensive listing of foodservice products and companies. It includes numerous indexes and entry points. It is updated annually, though most libraries could get by with a new edition only every few years.

National Restaurant Association (2011), Restaurant Industry Forecast, National Restaurant Association, Washington, D.C.

An annual slim volume produced by the nation's foremost restaurant association, this must-have work serves up a heaping plateful of statistics, market research, and trends on all facets of the domestic restaurant industry.

Tlapa, C.A., Miller, R.K., and Washington, K. (2011), Restaurant, Food \& Beverage Market Research Handbook, Richard K. Miller \& Associates, Loganville, GA. As with most of Richard Miller's handbooks, this source consists mostly of brief summaries and references to material published in trade magazines, industry websites, books, and other sources. Its usefulness is in providing helpful starting points, identifying major sources, and conceptualizing a topic.

Miscellaneous Foodservice Works:

Clarkson, J. (2009), Menus from History: Historic Meals and Recipes for Every Day of the Year, Greenwood Press, Santa Barbara, CA.

This work operates under the premise of providing a historical menu for every day of the year, spanning hundreds of years of culinary history. This unique approach results in a fascinating work that can be useful for cooks, food historians, and many others. Indexes offer access points by chronology, country, occasion, and recipe, and a glossary and bibliography is also included.

Hill, K.T. (2010), Career Opportunities in the Food and Beverage Industry, Ferguson, New York, NY.

Since most hospitality programs are very career-oriented, students frequently need information about jobs and career paths. This book, part of the well-known Career 
Opportunities in... series, provides a good overview of careers in the foodservice industry. Entries cover duties, training, education, salaries, employment prospects, advancement prospects, and much more. Listings of relevant schools, associations, and periodicals are also included.

Pennington, J.A.T. and Spungen, J. (2010), Bowes \& Church's Food Values of Portions Commonly Used, Lippincott, Williams and Wilkins, Philadelphia, PA.

This is a time-honored source for in-depth nutritional and compositional information about thousands of different foods. For basic serving size information, another standard source is Chef's Book of Formulas, Yields, and Sizes (Wiley, 2003).

Plunkett Research (2012), Plunkett's Food Industry Almanac, Plunkett Research, Houston, TX.

See the General Resources category below for a description of this and other Plunkett's almanacs.

Zagat Survey (2012), America's Top Restaurants, Zagat, New York, NY.

This classic source is still a trusted and relatively objective guide to top restaurants in 45 major American metropolitan areas. Each establishment is rated on food, décor, service, and cost.

\section{Lodging Resources}

The lodging industry in the United States is a large enterprise, employing nearly two million workers and generating over $\$ 150$ billion in sales each year. It includes over 52,000 properties in the United States with a total of over 4.9 million guestrooms (AHLA, 2013).

Making up the lodging industry are such areas as hotels, motels, resorts, casinos, bed and breakfasts, inns, guesthouses, and campgrounds. Occasionally, areas such as timeshare properties, condominiums, and vacation ownership properties are also included in this category. Materials relating to the lodging industry can be expensive, so libraries may have to make choices regarding areas of emphasis or facets of the industry to cover.

Casinos and Gaming:

Casino City (2012), Global Gaming Almanac, Casino City, Newton, MA.

This hefty book (also available as a subscription or as a CD) provides statistics, market research data, and other information for the gaming industry as a whole and by country. Casino City also publishes a number of other key casino publications, including the North American Gaming Almanac, Indian Gaming Industry Report, Internet Gambling Report, and the Gaming Business Directory, the last providing detailed listings of casinos, horse tracks, dog tracks, cruise ships, online casinos, industry suppliers, and more. A smaller and more consumer-oriented casino directory is the American Casino Guide (Casino Vacations, 2012). 
Hashimoto, K. and Fenish, G.G. (2007), Casino Dictionary: Gaming and Business Terms, Pearson, Upper Saddle River, NJ.

A handy basic dictionary covering the vocabulary and jargon of games of chance, cheating methods, management areas, and other areas relating to the casino industry.

Miller, R.K. and Washington, K.D. (2012), Casinos, Gaming \& Wagering, Richard K. Miller \& Associates, Loganville, GA.

As with most of Richard Miller's handbooks, this source consists mostly of brief summaries and references to material published in trade magazines, industry websites, books, and other sources. It is useful in bringing it all together in one cover and for providing starting points to assist the researcher in delving deeper into various facets of the industry.

Thompson, W.N. (2001), Gambling in America: An Encyclopedia of History, Issues, and Society, ABC-CLIO, Santa Barbara, CA.

This key one-volume work includes encyclopedic entries on all aspects of gambling in America, as well as a chronology, a glossary of terms, bibliographies, and other useful features.

Lodging:

PKF Hospitality Research (2011), Trends in the Hotel Industry (USA ed.), PKF Hospitality Research, New York, NY.

Produced annually, this report offers broad trends and data pertaining to the United States lodging industry, including breakdowns by geographic region and type of hotel. Libraries with more generous budgets may be able to subscribe to a customized lodging information package through Smith Travel Research, the leading market research firm in the lodging industry. Also useful are publications such as the Green Book, published annually by the trade magazine Hotel Business, and the Ultimate Hotel Guide, published annually by the trade magazine Travel Weekly.

Professional Association of Innkeepers International (2011), Industry Study of Innkeeping Operations and Finance, PAII, Haddon Heights, NY.

This annual report is the best source of data on the small "inn" and "bed \& breakfast" segment of the lodging industry. It includes ownership profiles, property characteristics, revenues and expenses, compensation levels, and much more. For a basic directory of such establishments, a standard source is Complete Guide to Bed \& Breakfasts, Inns, \& Guesthouses in the United States, Canada, \& Worldwide (Lanier, 2011).

Woodall's Publications (2012), Woodall's North American Campground Directory, Woodall's, Guilford, CT.

A classic reference source in publication since 1936, Woodall's provides a comprehensive listing of campgrounds in the United States and Canada. Most libraries will need a new edition only every few years. 
Timeshares:

American Resort Development Association and Ernst \& Young (2012), State of the Vacation Timeshare Industry, ARDA International Foundation, Washington, D.C. This annual report is the best source for current statistical and market information on the United States timeshare industry, including resort size, type, sales, geographic region, and more. The American Resort Development Association (ARDA) also publishes several related titles that specialized collections may wish to acquire, such as the Economic Impact of the Timeshare Industry on the U.S. Economy, the Shared Vacation Ownership: Owners Report, and the Timeshare Industry Resource Manual.

Interval International (2011), Membership Profile, Interval International, Miami, FL. This slim volume and related Interval International reports (Future Timeshare Buyers, Affluent Shared Ownership Buyer, etc.) focus on the U.S. timeshare market and buyer, featuring the results of surveys conducted by the market research firm. These works complement ARDA's extensive series of timeshare publications (see previous entry).

\section{Meetings and Events Resources}

The meetings and events industry is slowly gaining recognition, and employment prospects are surprisingly good - and projected to continue growing in the future. In 2002, the U.S. Department of Labor recognized "meeting and convention planners" as a separate occupation for the first time, estimating that around 37,000 Americans were coordinating all aspects of professional meetings and events, including choosing meeting locations, arranging transportation, and coordinating other details ("For What It's Worth, 2002). By 2010, the Department of Labor broadened the title to "meeting, convention, and event planners" and estimated that more than 71,000 Americans were working in the field. Moreover, it estimated employment growth between 2010 and 2020 to be a staggering 44 percent (BLS, 2013).

The meeting and convention industry includes areas such as meetings, incentives, conventions, expositions, trade shows, special events, festivals, and conferences.

Adamson, M.W. and Segan, F. (2008), Entertaining from Ancient Rome to the Super Bowl: An Encyclopedia, Greenwood Press, Westport, CT.

A two volume set offering short- to medium-length articles on celebrations and events of all types, including festivals, holidays, sporting events, and much more. No other work covers the history and culture of entertaining so thoroughly.

Chase's Calendar of Events (2013), McGraw-Hill, New York, NY.

A must-have classic reference work, this annual book can provide ideas and background for planners of holidays, festivals, and celebrations of all types. A searchable CD-Rom now accompanies the book.

Connell, J. and Page, S. (2010), Event Tourism: Critical Concepts in Tourism, Routledge, New York, NY. 
An impressive set covering the intersection of events and tourism in four thematic volumes. Most of the chapters are reprints of previously published journal articles, book chapters, and conference papers, but there is great value in having them brought together all in one carefully arranged source.

Findling, J.E. and Pelle, K.D. (2008), Encyclopedia of World's Fairs and Expositions, McFarland, Jefferson, NC.

This single-volume work provides an article on every world's fair (or similar type of exposition) in chronological order, from London 1851 to Shanghai 2010. Also included are several useful appendices, including ones on fair officials, a listing of smaller or canceled fairs, and an extensive bibliography.

Goldblatt, J. and Nelson, K.S. (2001), International Dictionary of Event Management, Wiley, New York, NY.

This source remains the most current dictionary focusing on the field of event management. An alphabetical listing of terms and definitions is followed by a categorical listing by knowledge domain, designed to be helpful for those studying for the Certified Special Events Professional exam.

Miskelly, M. (2012), Trade Shows Worldwide, Gale, Detroit, MI.

Arranged in three volumes, this annual source provides the most extensive listing of trade show listings, sponsors, organizers, facilities, and rankings.

PKF Hospitality Research (2012), Trends in the Conference Center Industry, PKF Hospitality Research, Atlanta, GA.

As with most PKF publications, this report is pricy but chock-full of data, charts, and graphs on the conference center industry, including revenue, rates, occupancy, meeting statistics, human resources, and more.

Page, S.J. and Connell, J. (2012). Routledge Handbook of Events, Routledge, New York, NY.

Similar to other Routledge Handbooks, this work features chapters written by experts on all facets of events studies. The chapters are excellent sources in themselves and usually feature extensive references and further reading suggestions.

Salesman’s Guides (2012), Association Meeting \& Event Planners, Salesman’s Guides, Richmond, VA.

Published annually, this directory covers more than 17,000 state and national associations that hold meetings. It can be useful for industry professionals as well as for students seeking to find employment in this rapidly growing field. Other specialized directories are also available from the same publisher, such as Corporate Meeting \& Event Planners, Medical Meeting \& Event Planners, and Religious Meeting \& Event Planners.

Travel Industry Association of America (2006), U.S. Domestic Business and Convention Travel, TIAA, Washington, D.C. 
Although pricy, this resource provides an unparalleled amount of data about business and convention travel in the United States, including travel volume, demographics, and trip characteristics.

Wallace, E., Mathai, M., and Heath, A. (2008), Convention Industry Council Manual, Convention Industry Council, Washington, D.C.

Designed to be a guide for meeting professionals as well as a study aid for the Certified Meeting Professional exam, this source is also a useful reference source for event management students. Chapters cover all aspects of meeting planning, such as budgeting, venue selection, risk management, food and beverage, transportation, ethics, and much more, often including sample forms, checklists, and other practical features.

\section{Theme Park \& Attractions Resources}

Of all the diverse industries that comprise the field of hospitality management, theme parks and attractions has probably received the least amount of scholarly attention —at least outside of locales where theme parks are heavily concentrated, such as Florida, California, the Northeast, and the Midwest. However, interest in theme parks and attractions is clearly on the rise, especially as the field continues to grow and diversify. In 2010, approximately 290 million people went through the turnstiles of theme parks and attractions in the United States, generating more than $\$ 12$ billion in revenue (IAAPA, 2013).

The industry includes areas such as general amusement parks, specialized theme parks (historical, cultural, geographical, etc.), water parks, family entertainment centers (go-carts, miniature golf, etc.), zoological parks (especially those that incorporate elaborate rides and shows, such as Sea World), and natural attractions (botanical gardens, Grand Canyon, etc.).

International Association of Amusement Parks and Attractions (2011-12), Amusement Park Benchmark Study, IAAPA, Alexandria, VA.

From the foremost industry association on amusement parks, this report provides a comprehensive overview of the amusement park business, including operational characteristics, pricing, attendance, revenue, marketing, and more. IAAPA also publishes several other key reports on the attractions industry, such as Managing Attractions for More Profit, Family Entertainment Center Benchmark Study, and Water Park Benchmark Study.

Jeffers, G. and Rubin, J. (2013), Global Attractions Attendance Report, Themed Entertainment Association, available online at https://www.teaconnect.org/sites/default/files/misc/files/2012_theme_index_combined_13_online.pdf (accessed 15 July 2013).

A vital annual report on the global attractions industry, including attendance estimates, trends, and analysis. At one time it was published only in industry trade magazines, but for the last several years it has been freely available through the Themed Entertainment Association (TEA) website. 
Smith, David (2006), Disney A to Z: The Official Encyclopedia, Disney Editions, New York, NY.

As the title implies, this book is the best single-volume reference to the vast Disney empire, including theme parks, movies, television shows, songs, personalities, and more. Also useful is Chris Stodder's more narrowly focused Disneyland Encyclopedia (Santa Monica Press, 2012).

Travel Industry Association (2006), Economic Impact of the Attractions Industry, TIA, Washington, D.C.

A joint production of the Travel Industry Association and the International Association of Amusement Parks \& Attractions, this brief report provides a wealth of statistical, economic, and demographic research on the attractions industry.

\section{Travel \& Tourism Resources}

As with the field of hospitality management as a whole, the travel and tourism industry is actually a collection of closely-related enterprises, including such areas as travel, tourism (which may be further subdivided into categories such as ecotourism, heritage tourism, etc.), airlines, cruise lines, travel agencies, and tour operators.

Collectively, domestic and international travelers spend over $\$ 800$ billion in the United States each year, and direct travel-generated payroll exceeds \$195 billion (USTA, Economic Review, 2011-12).

There are many important resources pertaining to the various areas of travel and tourism, and libraries may need to make choices regarding areas of emphasis and depth of coverage.

Collins, V.R. (2008), Tourism Society's Dictionary for the Tourism Industry, CABI, Cambridge, MA.

This is a small, handy general tourism dictionary with brief definitions on thousands of terms. CABI also published A Dictionary of Travel and Tourism Terminology (2005), which features longer and more in-depth entries. Key Concepts in Tourism (Palgrave Macmillan, 2007) has a similar approach, providing fewer entries but much longer miniencyclopedic coverage of key issues and terms.

Jamal, T. and Robinson, M. (2009), SAGE Handbook of Tourism Studies, SAGE, Los Angeles, CA.

This highly-recommended work provides an excellent introduction to the sprawling subject of tourism studies through medium-length chapters on different aspects of the field.

Entries are written by experts and include extensive references at the end. Upper-level undergraduates and graduate students will especially benefit from this book's in-depth explorations of difficult or poorly-covered areas of tourism studies.

Lück, M. (2008), Encyclopedia of Tourism \& Recreation in Marine Environments, CABI, Cambridge, MA. 
Marine tourism covers a wide range of industries and subject areas, and this one-volume encyclopedia provides a good introduction to its various facets, mostly through short to medium-length entries signed by experts. An extensive list of references and further reading suggestions is included at the end.

Miller, R.K. and Washington, K. (2011-12), Travel \& Tourism Market Research Handbook, Richard K. Miller \& Associates, Loganville, GA.

This annual publication is a handy starting point for a myriad of travel and tourism inquiries. Most of the content is pulled from other books, trade magazines, and websites, but this work brings it all together and often points the reader to the best industry association or trade source for more in-depth research on the topic. Topics covered include agritourism to zoos and everything in between.

National Golf Foundation (2009), Golf Travel in the U.S., NGF, Jupiter, FL. This brief report is one of the few sources with demographic and market research data on golf travelers, defined as adults "who traveled on business or vacation and played golf at least once while on a trip.”

New Strategist Publications (2010), Who's Buying for Travel, New Strategist, Ithaca, NY. Based on data from the Bureau of Labor Statistics' Consumer Expenditure Survey, this report provides data on travel categories that might otherwise be difficult to track, such as spending on gasoline, luggage, taxi fares, and vehicle rentals.

Organisation for Economic Co-operation and Development (2010), OECD Tourism Trends \& Policies, OECD, Paris, France.

This work is a key source for learning about the organizational and logistical nature of tourism policy and practice in 42 of the world's most developed tourism economies. Also included are overview chapters exploring hot-button issues such as sustainable tourism and destination marketing.

Speake, J. (2003), Literature of Travel and Exploration: An Encyclopedia, Fitzroy Dearborn, New York, NY.

This highly readable three-volume work is the most complete reference source on travel and exploration literature, including entries on individuals, places, methods of transportation, organizations, societies, and much more. Entries are signed and include extensive references and further reading lists.

\section{U.S. Travel Association (2010-11), Economic Review of Travel in America, USTA,} Washington, D.C.

The U.S. Travel Association (formerly known as the Travel Industry Association) publishes many must-have publications covering the domestic travel and tourism industries. This work provides background, data, and statistics on the economic impact of travel from a variety of different angles. Other key USTA publications include Impact of Travel on State Economies, Outlook for Travel \& Tourism, Survey of U.S. State and Territory Tourism Offices, Travel and Tourism Works for America, and Travelers' Use of the Internet. 
Ward, D. (2012), Complete Guide to Cruising \& Cruise Ships, Berlitz Publications, London, UK.

Both this publication and Stern's Guide to the Cruise Vacation (Pelican, 2012) are geared more towards consumers, but they can also provide excellent background material for students researching the cruise industry. Published annually, they provide overviews of the current cruise line industry, including major cruise lines, ships, ports of call, and other practical information. They can serve as complements to more scholarly (but less frequently updated) resources such as Cruise Tourism: Current Situations and Trends (see the World Tourism Organization entry below).

Williams, S. (2004), Tourism: Critical Concepts in the Social Sciences, Routledge, New York, NY.

This four-volume set mostly consists of reprints of book chapters, journal articles, and conference proceedings from the 1970s through the early 2000s. As such, libraries with extensive historical holdings in the field may get by without it, but for most others it may serve as a crucial source of past key writings, all brought together in one place and arranged in meaningful categories.

World Tourism Organization (2012), Compendium of Tourism Statistics, WTO, Madrid, Spain.

This annual volume provides official tourism data (inbound, outbound, domestic, employment, and other statistics) for more than 200 countries and territories. A companion volume, the Yearbook of Tourism Statistics, provides more detail about nonresident arrivals at national borders. The WTO also publishes numerous important tourism reports every year: recent publications have included Budgets of National Tourism Organizations (2010), Cruise Tourism: Current Situations and Trends (2010), Handbook on Tourism Destination Branding (2009), Measuring the Economic Impact of the Meetings Industry (2006), Youth Travel Matters: Understanding the Global Phenomenon of Youth Travel (2008), and many others. Libraries dedicated to supporting extensive tourism collections should inquire about becoming a WTO Depository Library (http://publications.unwto.org/en/node/29763), which entitles the library to receive WTO publications at a greatly reduced price in exchange for preserving and providing public access to the material.

\section{Hospitality Management Databases and Indexes}

Listed below are the indexes and databases that specialize in resources that are directly applicable to the study of hospitality management. Of course, the librarian assisting hospitality students will also need to turn to general interest databases or to ones focused on business, company information, economics, news, and science.

Food Science Source database, EBSCO Publishing, Ipswich, MA, available by subscription. 
This database includes articles and reports from thousands of publications, covering all aspects of the food industry. The coverage is tailored to food science practitioners and technical specialists, and there is little overlap with more general databases such as Hospitality \& Tourism Complete.

Hospitality \& Tourism Complete database, EBSCO Publishing, Ipswich, MA, available by subscription.

As the name implies, this is the premier database for the fields of hospitality and tourism. It includes nearly a million records, with coverage dating back to the 1930s, and includes a lot of full text. Hospitality \& Tourism Index, an index with similar coverage but very little full text, is also available.

Leisure Tourism Abstracts database, CABI, Oxfordshire, UK, available by subscription. The focus of this database is on leisure studies, recreation, and tourism, with more than 100,000 records dating back to the early 1970s. It is especially valuable for its coverage of non-journal literature that is not indexed in a lot of other sources, such as book chapters, conference proceedings, and theses and dissertations.

Mintel database, Mintel Group Ltd., Chicago, IL, available by subscription.

Mintel, a market intelligence firm, offers several useful products for libraries supporting tourism collections, including Country Reports and Travel and Tourism Analyst reports. The in-depth country reports, for example, are typically 20 or more pages in length and include a special focus on travel and tourism within the destination.

\section{Hospitality Management Websites and Electronic Lists}

As with any academic subject, some useful websites applicable to hospitality management are freely available online. Key statistics and news can often be found on government sites or on the pages of professional associations or organizations. Such organizations often sell specialized books, reports, or audiovisual programs as well. The following websites are among the most useful for librarians supporting hospitality management collections.

Websites:

Airlines for America, http://www.airlines.org (accessed 15 July 2013)

American Culinary Federation, http://www.acfchefs.org (accessed 15 July 2013)

American Hotel \& Lodging Association, http://www.ahla.com (accessed 15 July 2013)

American Resort Development Association, http://www.arda.org (accessed 15 July 2013)

American Society of Golf Course Architects, http://www.asgca.org (accessed 15 July 2013)

Beer Institute, http://www.beerinstitute.org (accessed 15 July 2013)

Club Managers Association of America, http://www.cmaa.org (accessed 15 July 2013)

Convention Industry Council, http://www.conventionindustry.org (accessed 15 July 2013)

Cruise Lines International Association, http://www.cruising.org (accessed 15 July 2013)

Federal Aviation Administration, http://www.faa.gov (accessed 15 July 2013) 
International Association of Amusement Parks \& Attractions, http://www.iaapa.org (accessed 15 July 2013)

Meeting Professionals International, http://www.mpiweb.org (accessed 15 July 2013)

Modern Brewery Age, http://www.breweryage.com (accessed 15 July 2013)

National Restaurant Association, http://www.restaurant.org (accessed 15 July 2013)

Office of Travel \& Tourism Industries, http://tinet.ita.doc.gov (accessed 15 July 2013)

Pacific Asia Travel Association, http://www.pata.org (accessed 15 July 2013)

Professional Convention Management Association, http://www.pcma.org (accessed 15

July 2013)

Research and Innovative Technology Administration, http://www.rita.dot.gov (accessed 15 July 2013)

Themed Entertainment Association, http://www.teaconnect.org (accessed 15 July 2013)

Tourism Offices Worldwide Directory, http://www.towd.com (accessed 15 July 2013)

Travel.State.Gov, http://travel.state.gov (accessed 15 July 2013)

United States Golf Association, http://www.usga.org (accessed 15 July 2013)

UNLV Center for Gaming Research, http://gaming.unlv.edu (accessed 15 July 2013)

U.S. Travel Association, http://www.ustravel.org (accessed 15 July 2013)

Wine Institute, http://www.wineinstitute.org (accessed 15 July 2013)

World Golf, http://www.worldgolf.com (accessed 15 July 2013)

World Tourism Organization, http://www.unwto.org (accessed 15 July 2013)

Electronic Mailing Lists:

Hospitality-Lib (2004-present), email discussion list devoted to hospitality librarianship, managed at the University of Central Florida, with subscription information available at http://library.ucf.edu/rosen/hospitalitylib.php (accessed 15 July 2013).

\section{References}

American Hotel and Lodging Association (2013), “2013 lodging industry profile,” available at http://www.ahla.com/content.aspx?id=35603 (accessed 15 July 2013).

American Library Association (2011), ALA Guide to Economics \& Business Reference, American Library Association, Chicago, IL.

Bureau of Labor Statistics, U.S. Department of Labor (2013), Occupational Outlook Handbook, available at http://www.bls.gov/ooh/ (accessed 15 July 2013).

Council on Hotel, Restaurant, and Institutional Education (2006), Guide to College Programs in Hospitality, Tourism, \& Culinary Arts, International CHRIE, Richmond, VA.

Edmondson, B. (1996), Hospitality Leadership: The Cornell Hotel School, Cornell Society of Hotelmen, Ithaca, NY. 
"For what it's worth, the government says planners really exist" (August 5, 2002), Meeting News, vol. 26, no. 11, pp. 8.

International Association of Amusement Parks and Attractions, “Amusement park and attraction industry statistics” (2013), available at http://www.iaapa.org/pressroom/Amusement_Park_Industry_Statistics.asp (accessed 15 July 2013).

Krupar, E.M. and Auer, N.J. (2005), “Avoiding accidental tourism: reference resources for travel research,” Journal of Library Administration, Vol 43, No. 3/4, pp. 209-225.

Livingston, J.S. (1985), “The electronic age, then and now,” Cornell Hotel \& Restaurant Administration Quarterly, Vol 26, No. 1, pp. 20-21.

National Restaurant Association, "Facts at a Glance” (2013), available at http://www.restaurant.org/News-Research/Research/Facts-at-a-Glance (accessed 15 July 2013).

“Outstanding business reference sources” (Winter 2011), Reference \& User Services Quarterly, vol. 51, no. 2, pp. 122-126.

Ryan, J.K. (1996), "Looking back at the past 50 years: a chronological history of CHRIE,” Hospitality \& Tourism Educator, Vol 8, No. 2/3, pp. 33-36.

U.S. Travel Association (2011-2012), Economic Review of Travel in America, U.S. Travel Association, Washington, D.C.

U.S. Travel Association (2010-2011), Travel and Tourism Works for America, U.S. Travel Association, Washington, D.C.

United Nations World Tourism Organization (2013). UNWTO Tourism Highlights 2013 Edition. United Nations World Tourism Organization, Madrid, Spain.

Zabel, D. (2003), “The best of the web: hospitality and tourism web sites,” Journal of Business \& Finance Librarianship, Vol. 8, No. 3/4, pp. 167-179. 